\title{
Advances in medical education and practice: what millennial medical students say about flipped learning
}

This article was published in the following Dove Press journal:

Advances in Medical Education and Practice

28 September 2017

Number of times this article has been viewed

\section{Mirza Shaheer Baig Habeeba Suleman Mallu}

Barts and The London School of Medicine and Dentistry, London, UK

Correspondence: Mirza Shaheer Baig Barts and The London School of Medicine and Dentistry, 4 Newark Street, Whitechapel, London EI 2AT, UK Tel +447908608819

Email m.s.baig@smdI4.qmul.ac.uk

\section{Dear editor}

We thank Pettit et al ${ }^{1}$ for their study, which explores the opinions of millennial medical students with regards to "flipped learning". As penultimate year medical students, we place great value in the analysis of feedback from students to develop an improved curriculum. We share the view that our generation has a desire for variety and flexibility in pedagogical formats. It must be noted, however, that student preference may change as they progress through medical school and a key factor in developing an effective curriculum is assessing the impact on attainment in addition to collecting student feedback.

Medical schools in the UK are increasingly adopting a flipped learning approach where students undertake core learning components independently while in-class time is allocated to interactive student-centered activities to consolidate learning. The curriculum at Barts and The London School of Medicine places considerable emphasis on problem-based learning, which is a similar pedagogy to flipped learning whereby students research specific learning objectives based on a patient scenario, before convening with peers at a case-based discussion. ${ }^{4}$ There is a wide variety among medical schools with regards to the extent of flipped learning in the curriculum, ${ }^{2-4}$ and Pettit et al have sought to find students' views on the optimum amount of a curriculum to flip. ${ }^{1}$

The authors make a valid point that students are more attentive learners when the format gives them greater choice. ${ }^{1}$ It must also be noted that diversity in the millennial generation is a key factor in determining effective teaching strategies. Pettit et al mention that millennials are technology savvy, and this may be true in comparison to previous generations. However, from our personal experiences, we know students range from those who use a pen and notepad in lectures to those who type up notes on their laptop. The variety in learning styles would explain the surprising result in this study which showed that many students preferred more than $50 \%$ of lecture-based classes. ${ }^{1}$

A key limitation mentioned by the authors states that only first year students were used in this study. ${ }^{1}$ We believe that learning styles develop as students advance through their degree and flipped learning may become preferable in later clinical years which require more independence. A significant portion of the third year curriculum at our institution adopts a flipped learning approach. The endocrinology module is delivered as pre-recorded vodcasts followed by in-class case-based discussions. This proved to have the highest average attainment across the year group in comparison to other modules taught in traditional 
lecture-based classes. Improved student performance with flipped learning is further demonstrated in other studies. ${ }^{5}$

As senior medical students, we strongly advocate for increased implementation of flipped learning in the medical school curriculum. Further research is required to assess the value of this pedagogical approach in student attainment in addition to the study carried out here by Pettit et al. ${ }^{1}$ We thank them for their work and hope that this leads to continuing improvement of medical education which develops competency and compassion in tomorrow's doctors.

\section{Disclosure}

The authors report no conflicts of interest in this communication.

\section{References}

1. Pettit R, McCoy L, Kinney M. What millennial medical students say about flipped learning. Adv Med Educ Pract. 2017;8:487-497.

2. MBBS Program Information. Uclacuk; 2017. Available from: http://www. ucl.ac.uk/medical-school/study/undergraduate/mbbs-program. Accessed August 15, 2017.

3. Courses - School of Clinical Medicine. School of Clinical Medicine; 2017. Available from: https://www.medschl.cam.ac.uk/education/ courses/. Accessed August 15, 2017.

4. MBBS curriculum map for Barts and The London School of Medicine and Dentistry. 2010. Available from: http://compas.smd.qmul.ac.uk/. Accessed August 15, 2017.

5. Pierce R, Fox J. Vodcasts and active-learning exercises in a "flipped classroom" model of a renal pharmacotherapy module. Am J Pharm Educ. 2012;76(10):196.

Dove Medical Press encourages responsible, free and frank academic debate. The content of the Advances in Medical Education and Practice 'letters to the editor' section does not necessarily represent the views of Dove Medical Press, its officers, agents, employees, related entities or the Advances in Medical Education and Practice editors. While all reasonable steps have been taken to confirm the content of each letter, Dove Medical Press accepts no liability in respect of the content of any letter, nor is it responsible for the content and accuracy of any letter to the editor.

\section{Publish your work in this journal}

Advances in Medical Education and Practice is an international, peerreviewed, open access journal that aims to present and publish research on Medical Education covering medical, dental, nursing and allied health care professional education. The journal covers undergraduate education, postgraduate training and continuing medical education including emerging trends and innovative models linking education, research, and health care services. The manuscript management system is completely online and includes a very quick and fair peer-review system. Visit http://www.dovepress.com/testimonials.php to read real quotes from published authors.

Submit your manuscript here: http://www.dovepress.com/advances-in-medical-education-and-practice-journal 